\title{
Comparative status of insecticide resistance in the Helicoverpa and Heliothis species (Lepidoptera: Noctuidae) of south India
}

\author{
Deepak R. Jadhav \\ International Crops Research Institute for the Semi-Arid Tropics, Patancheru, \\ India
}

Nigel J. Armes

Natural Resources Institute, Chatham Maritume, UK

\begin{abstract}
Helicoverpa armigera (Hubner), $H$ assulta Cuenée and Heliothis peltigera (Denis \& Schiffermuller) were collected as mixed populations from safflower and the wild host Datura metel, from Patancheru Andhra Pradesh, India, in 1992 and 1993, and their toxicological responses to insecticides determined Both Helicoverpa armigera strains were highly resistant to cypermethrn fenvalerate endosulfan and quinalphos insecticides based on resistance ratios relative to laboratory reared susceptible strans There was no evidence of resistance development in $H$ assulta and Heliothis pelligera to the same chemicals Light trap data collected from 1974 to 1987 showed that Helicoverpa armigera was at least $100 \times$ more abundant than the other two species over most of the cropping season Peak catches of $H$ assulta and Heliothis peltigera were confined to defined times in the season, corresponding with the flowering and fruting periods of their respective host plants August-October for Helicoverpa assulta and November-December for Heliothis peligera Helicoverpa armigera on the other hand, because of its high polyphagy on commercial and wild hosts, was abundant between August and Apnl. Resistance has not developed in $H$ assulta and Heliothis peltigera in southem India, probably because of their restricted host range, limiting exposure to insecticides
\end{abstract}

\section{Introduction}

Heliothune moths of the fanily Noctudae include some of the most damaging agneultural pests worldwide In Indsa, three Heliathus species (taken in this context to include the Helicoorerpa species) have been recorded. viz. Helicoorerpa armagera (Hübner), Helcooverpa assulta Guenée and Helothis pelhgere (Denis \& Schiffermiller)

The highly polyphagous species Helcooerpa armugera, is mdely distributed from southem Europe through Afrea and Assa to Australasia and the South Paclic. It is the most

Correpondence N.J Ames Crop Proketion Division ICRISAT Patancheru PO. Hyderabad Andhra Pradesh 502324 India senous pest of the three described, having been reported as feeding on over 180 host plants from 45 plant families in India alone (Manjunath of al, 1989) It is a particularly important pest of cotton, legumes and tomatoes where crop losses are considerable It commonly destroys more than half the yreld with estimates of annual losses in India amounting to US5300-500 million to cotton and pulses alone (King, 1994) In recent years, it has developed ressistance to certain molecules in all the established chemical groups of insecticides avaliable to Indian farmers for boll. worm control (MCCaffery of al, 1989; Ames of al., 1992a), and field control failures ase now common. Overuse of insectecides againat ineecticide resiotank H. amigera has exacerbated the problem by suppressing natural enemies, 
thereby allowing much larger populations to develop on field crops. It is likely that the impact of a succession of suitable host plants, insecticide resistance and natural enemy suppression has made $H$. armigera the dominant pest in cotton agro-ecosystems in the Indian subcontinent over the past ten years.

Helicoverpa assulta is found throughout Africa. Asia, parts of Australasia and the South Pacific but unlike $H$. armigera, it is oligophagous with larvae primarily feeding on solanaceous plants. In India the peincipal hosts are tobacco and wild hosts in the genus Datura (Bhatnagar \& Davies, 1978; Manjunath et al, 1989). Potato has been reported as an occasional host but we could not confirm this during five years of intensive field surveys in southern India Oadhav, unpublished data). In the Far East it is an important pest of chillies and bell peppers (Capsicum spp.) (Cho \& Boo, 1988), but, in India, $H$. amigera is the usual species found on Capsicum spp. Helicoverpa assulta is considered to be a minor pest, but its importance may be underestimated because of the similarity of both larvae and moths to those of $H$. armigera. There are no reports of control difficulties or insecticide resistance development in this species in the Indian subcontinent. However, in South Korea, control failures on Capsicum crops have been attributed to insecticide resistance (Lee \& Boo. 1985).

Heliothis peltigera is polyphagous with a wide geographic distribution from central and southem Europe, the Canary Islands, Asia Minor and India. In India, it has been reported on seven host plants from five families (Manjunath at al., 1976, 1989). The only commercial host is safflower, Carthamus tinctorius (Compositae). In Israel it is a pest of omamental and medicinal plants, safflower, tobacco, cotton, chickpea, fodder crops, grapevines and various fruit trees (Yathom. 1971: Avidov \& Harpaz, 1989; Ibrahim \& Fayad. 1989). There have been no published reports of insecticide resistance developing in this species.

During field collections of Helicoverpa armigera larvae in India over twenty years, it was quite common to come across mixed populations of $H$. armigera and Heliothis peltigera on safflower (Pawar et al., 1985) and Helicoverpa armigera and $H$. assulta on tobacco, and all three species together on wild hosts in the family Solanaceae. In view of this overlapping host range and the possibility of confusing $H$. armigera with other heliothine species over much of its geographic range (e.g. Mohyuddin, 1989), this study was undertaken to determine the stakus of insecticide susceptibility in the three species in the southern Indian State of Andhra Pradesh. Further, we felt it was important to draw attention to the importance of correctly identifying Heliothis species in situations where management decisions for insecticide resistant and susceptible species may differ appreciably because of the widespread occurrence of resist. ance in Helicoverpa armigera in Asia.

\section{Materials and methods}

\section{Insects}

All species were collected as third to sixth instar larvae from hosk plants on the 1400 hs research farm of the International Crops Research Institute for the Semi-Arid Tropics (ICRISAT). ICRISAT Asia Center, Patanchenu, Andhra Pradesh, India, between November 1992 and July 1993. Heliothis peltigen larvae were collected randomly from fields of unsprayed saffiower covering an area of approximately 1.5 ha in November 1992 . Two other collec. tions were made from the wild host. Datura motel (Solanaceae), in April and July 1993. In April, mixed populations of Helicoverpa assulta and $H$. armigera were found on Datura. In July all three species coexisted on Daturn. Collections comprised at least two hundred larvae from any one host.

In the laboratory, larvae were transferred to a chickpea based semi-synthetic diet (Armes et al, 1992b). Species were determined at the adult stage (see below) and laboratory cultures of each species established from at least sixty individuals. Rearing and bioassay procedures were carried out at $25 \pm 2^{\circ} \mathrm{C}$ under natural photoperiod (c. $13: 11 \mathrm{~h}$ light:dark).

\section{Insecticides}

The following technical grade insecticides were used for bioassays: 6. $50: 50$ cis:trans cypermethrin $(900 \mathrm{~g} / \mathrm{kg}$; Zeneca Agrochemicals, UK); fenvalerate $(976 \mathrm{~g} / \mathrm{kg}$; Sumitomo Corp. Japan); endosulfan $(960 \mathrm{~g} / \mathrm{kg}$ : Hoechst, India); quinalphos ( $720 \mathrm{~g} / \mathrm{kg}$; Sandoz, India); monocrotophos $1680 \mathrm{~g} / \mathrm{kg}$ : Khatau Junker, India). The synergists piperonyl butoxide (pbo) and s,s,s,-tributyl phosphorotrithioate (DEF) were obtained from Goodeed Chemical Co. Ltd, UK., and Mobay Chemical Co., USA, respectively.

\section{Bioassay}

Serial dilutions of technical grade insecticides in acetone were applied topically as $1.0 \mu \mathrm{l}$ drops to the dorsal mesotho. racic region of individual F1 generation larvae weighing between $30-40 \mathrm{mg}$ as described by Anon. (1970). Control larvae were treated with acetone alone. In assays including the synergists pbo and DEF, these were applied as $1.0 \mu$ l drops to the mesothorax $15.20 \mathrm{~min}$ prior to the insecticide, at rates of $50 \mu \mathrm{g} / \mathrm{larva}$ and $20 \mathrm{\mu g} / \mathrm{larva}$ respectively. These rates were known to be sufficiently high to cause maximal inhibition of the metabolic system without causing mortality from the synergist alone. Each treatment and control group comprised at least 48 insects. After dosing, larvae were held individually on chickpea based diet in $7.5 \cdot \mathrm{ml}$ cells of 12-well tissue culture plates (Linbro, ICN Flow Ltd.). Mortality was assessed $144 \mathrm{~h}$ after treatment as previously described (Armes et al., 1992a). Control mortality was rare buk, where necessary, corrections were made using Abbott's formula (Abbott, 1925). Dose-mortality regressions were computed by Probit analysis (Finney, 1971). Significance of differences between probit lines were determined from Position $\chi^{2}$ test (to determine whether relative potencies differ from unity), and Parallelism $\chi^{2}$ test (to determine whether a common slope is adequate). Heterogeneity $\chi^{2}$ tests were performed on all probit lines to determine whether or not residual variation was consistent with binomial sampling (Ross, 1987).

\section{Light traps}

Two, or more usually three, Robinson pattem UV light traps were operated continuously on the ICRISAT Asia Center (IAC) farm between August 1974 and May 1987. Catches were sorted daily and the major pest species identified and counted. The identification of Halicoverpa 
Table 1. Log dose probit parameters for topically applied insecticides elther alone or in combination with synergists, to $30-40 \mathrm{mg}$ Holicooem armigere larva for two strains collected from the ICRISAT farm in 1993 .

\begin{tabular}{|c|c|c|c|c|c|}
\hline Insecticide treatment & $n$ & $L D_{w}(95 \%$ C.I. $)$ & $\mathrm{LD}_{\infty}$ & Slope \pm SE & $x^{2}$ \\
\hline \multicolumn{6}{|c|}{ Collection date: April 1993; Host plant: Datura } \\
\hline $\begin{array}{l}\text { Cypermethrin } \\
\text { Cypermethrin + Pbo } \\
\text { Fenvalerate } \\
\text { Fenvalerate+Pbo } \\
\text { Endosulfan } \\
\text { Quinalphos } \\
\text { Monocrotophos }\end{array}$ & $\begin{array}{l}432 \\
336 \\
432 \\
288 \\
384 \\
336 \\
432\end{array}$ & $\begin{array}{l}1.4(1.0-1.8) \\
0.13(0.10-0.16) \\
1.4(1.0-1.8) \\
0.090(0.08-0.11) \\
10.0(7.3-13) \\
0.66(0.51-0.82) \\
1.8(1.2-2.6)\end{array}$ & $\begin{array}{c}19 \\
0.57 \\
16 \\
0.25 \\
135 \\
3.5 \\
46\end{array}$ & $\begin{array}{l}1.1 \pm 0.1 \\
2.0 \pm 0.2 \\
1.2 \pm 0.1 \\
2.9 \pm 0.3 \\
1.1 \pm 0.1 \\
1.8 \pm 0.2 \\
0.9 \pm 0.1\end{array}$ & $\begin{array}{l}\text { NS } \\
\text { NS } \\
\text { NS } \\
\text { NS } \\
\text { NS }\end{array}$ \\
\hline \multicolumn{6}{|c|}{ Collection date: July 1993; Host plant: Datura } \\
\hline $\begin{array}{l}\text { Cypermethrin } \\
\text { Cypermethrin + Pbo } \\
\text { Fenvalerate } \\
\text { Fenvalerate+Pbo } \\
\text { Endosulfan } \\
\text { Quinalphos } \\
\text { Quinalphos + DEF } \\
\text { Monocrotophos } \\
\text { Monoctotophos +DEF }\end{array}$ & $\begin{array}{l}288 \\
255 \\
224 \\
240 \\
279 \\
312 \\
336 \\
404 \\
254\end{array}$ & $\begin{array}{l}0.28(0.21-0.37) \\
0.070(0.05-0.09) \\
0.93(0.05-1.4) \\
0.028(0.02-0.04) \\
3.0(2.4-3.8) \\
0.29(0.24-0.37) \\
0.10(0.07-0.12) \\
0.06(0.49-0.84) \\
0.70(0.48-1.1)\end{array}$ & $\begin{array}{c}2.4 \\
0.39 \\
10 \\
0.16 \\
15 \\
1.7 \\
0.76 \\
6.2 \\
11\end{array}$ & $\begin{array}{l}1.4 \pm 0.2 \\
1.7 \pm 0.2 \\
1.2 \pm 0.2 \\
1.7 \pm 0.3 \\
1.9 \pm 0.2 \\
1.7 \pm 0.2 \\
1.4 \pm 0.1 \\
1.3 \pm 0.2 \\
1.1 \pm 0.2\end{array}$ & $\begin{array}{l}\text { NS } \\
\text { NS } \\
\text { NS } \\
\text { NS } \\
\text { NS } \\
\text { NS } \\
\text { NS } \\
\text { NS } \\
\text { NS }\end{array}$ \\
\hline
\end{tabular}

"Heterogeneity Chi-square test; NS $=$ not significant, " $=P<0.05$.

amigera, $H$. assulta and Heliothis peltigera was checked against type specimens lodged in the IAC insect collection, the identities of which had been confirmed by the Common. wealth Institute of Entomology. UK.., identification service and by D.F. Hardwick (formerly of the Biosystematics Research Institute, Ottawa, Canada).

\section{Results}

\section{Helicoverpa armigera bioassays}

$L D_{x}$ 's for the pyrethroid insecticides were very high and variable between strains; with 5 and 1.5 -fold differences in cypermethrin and fenvalerate toxicities respectively be-
Iween the April and July collections (Position $\%^{2}, P<0.001$ ) (table 1). Slopes were low (range: 1.1-1.4) compared to log dose probit (Idp) statistics for the other two species and for insecticide susceptible $H$. amigara (Armes at al., 1992a). Pbo significantly synergized both cypermethrin and fenvalerate, recording synergist ratios of 4- to 11 - and 19. to 33-fold respectively (Position $\chi^{2} s, P<0.001$ ).

Similarly, values for endosulfan, quinalphos and monocrotophos $L D_{10}$ were significantly higher in April compared to July (Position $\%{ }^{2}, P<0.01$ ). High $L D_{10}$ s and relatively low slopes indicate that both $H$. amigera strains were resistant to endosulfan and the two organophosphate insecticides. DEF significantly synergized quinalphos (Position $\chi^{2}, P<0.01$ ) but not monocrotophos (Position $\%$, $P>0.05$ ).

Table 2. Log dose probit parameters for topically applied insecticides either alone or in combination with synergists, to $30-40 \mathrm{mg}$ Helicoverpo assulta larvae for two strains collected from the ICRISAT furm in 1993.

\begin{tabular}{|c|c|c|c|c|c|}
\hline Insecticide treatment & $n$ & $L D_{10}(95 \%$ C.i. $)$ & $L D_{n}$ & Slope \pm SE & $x^{2}$ \\
\hline \multicolumn{6}{|c|}{ Collection date: April 1993; Host plant: Datura } \\
\hline $\begin{array}{l}\text { Cypermethrin } \\
\text { Cypermethrin + Pbo } \\
\text { Fenvalerate } \\
\text { Fenvalerate + Pbo }\end{array}$ & $\begin{array}{l}336 \\
336 \\
240 \\
240\end{array}$ & $\begin{array}{l}0.009(0.006-0.010) \\
0.010(0.008-0.01) \\
0.021(0.02-0.02) \\
0.023(0.02-0.03)\end{array}$ & $\begin{array}{l}0.045 \\
0.029 \\
0.054 \\
0.062\end{array}$ & $\begin{array}{l}1.6 \pm 0.2 \\
2.7 \pm 0.3 \\
3.1 \pm 0.3 \\
3.0 \pm 0.4\end{array}$ & $\begin{array}{l}\text { NS } \\
\text { NS } \\
\text { NS } \\
\text { NS }\end{array}$ \\
\hline \multicolumn{6}{|c|}{ Collection date: July 1993; Host plant: Daturn } \\
\hline $\begin{array}{l}\text { Cypermethrin } \\
\text { Cypermethin + Pbo } \\
\text { Fenvalerate } \\
\text { Fenvalerate + Pbo } \\
\text { Endolaulfan } \\
\text { Quinalphos } \\
\text { Quinalphos +DEF } \\
\text { Monocrotophos } \\
\text { Monocrotophos +DEF }\end{array}$ & $\begin{array}{l}336 \\
295 \\
269 \\
231 \\
240 \\
240 \\
240 \\
329 \\
233\end{array}$ & $\begin{array}{l}0.006(0.005-0.007) \\
0.005(0.004-0.005) \\
0.013(0.01-0.02) \\
0.018(0.01-0.02) \\
0.93(0.77-1.1) \\
0.067(0.05-0.08) \\
0.027(0.02-0.03) \\
0.22(0.17-0.27) \\
0.28(0.22-0.36)\end{array}$ & $\begin{array}{l}0.020 \\
0.014 \\
0.049 \\
0.062 \\
3.3 \\
0.26 \\
0.13 \\
1.1 \\
1.7\end{array}$ & $\begin{array}{l}2.4 \pm 0.2 \\
2.6 \pm 0.3 \\
2.2 \pm 0.3 \\
2.3 \pm 0.3 \\
2.3 \pm 0.3 \\
2.2 \pm 0.3 \\
1.9 \pm 0.3 \\
1.8 \pm 0.2 \\
1.7 \pm 0.2\end{array}$ & $\begin{array}{l}\text { NS } \\
\text { NS } \\
\text { NS } \\
\text { NS } \\
\text { NS } \\
\text { NS } \\
\text { NS } \\
\text { NS }\end{array}$ \\
\hline
\end{tabular}

"Heterogeneity Chi-square test: NSS-not significant: " $-P<0.05$. 


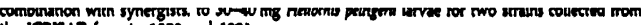
the KCRISAT form in 1992 and 1993.

\begin{tabular}{|c|c|c|c|c|c|}
\hline Insecticide treatment & $\cdots$ n & $6 D_{w}(95 \%$ C.I.) & $L D_{i}^{*}$ & Slope \pm St & $y^{2}$ \\
\hline \multicolumn{6}{|c|}{ Collection date: November 1992; Hosk plank: Sufflower } \\
\hline $\begin{array}{l}\text { Cypermethrin } \\
\text { Cypermethrin + Pbo } \\
\text { Fenvilerate } \\
\text { Fenvilerate + Pbo } \\
\text { Endosulfan } \\
\text { Quinalphos } \\
\text { Monocrotophos }\end{array}$ & $\begin{array}{l}299 \\
299 \\
288 \\
240 \\
246 \\
235 \\
228\end{array}$ & $\begin{array}{l}0.007(0.006-0.008) \\
0.007(0.006-0.009) \\
0.022(0.02-0.03) \\
0.058(0.05-0.07) \\
3.6(3.1-4.2) \\
0.035(0.03-0.04) \\
0.49(0.35-0.63)\end{array}$ & $\begin{array}{l}0.017 \\
0.035 \\
0.052 \\
0.11 \\
9.0 \\
0.065 \\
2.8\end{array}$ & $\begin{array}{l}3.4 \pm 0.4 \\
1.9 \pm 0.2 \\
3.3 \pm 0.3 \\
4.4 \pm 0.5 \\
3.2 \pm 0.3 \\
4.9 \pm 0.7 \\
1.7 \pm 0.3\end{array}$ & $\begin{array}{l}\text { NS } \\
\text { NS } \\
\text { NS } \\
\text { NS } \\
\text { NS } \\
\text { NS } \\
\text { NS }\end{array}$ \\
\hline
\end{tabular}

Collection date: July 1993; Host plant: Datura

\begin{tabular}{llllll} 
Cypermethrin & 236 & $0.008(0.006-0.01)$ & 0.029 & $2.2 \pm 0.3$ & NS \\
Cypermethrin+Pbo & 240 & $0.012(0.01-0.01)$ & 0.032 & $3.0 \pm 0.4$ & NS \\
Fenvalerate & 232 & $0.027(0.02-0.03)$ & 0.067 & $3.3 \pm 0.4$ & NS \\
Fenvalerate+Pbo & 240 & $0.051(0.04-0.06)$ & 0.12 & $3.3 \pm 0.4$ & NS \\
Endosulian & 240 & $2.1(1.0-2.0)$ & 0.5 & $2.7 \pm 0.3$ & NS \\
Quinilphos & 240 & $0.046(0.04-0.05)$ & 0.11 & $3.4 \pm 0.5$ & NS \\
Quiniphos+DEF & 272 & $0.040(0.03-0.05)$ & 0.15 & $2.2 \pm 0.3$ & NS \\
Monocrotophos & 503 & $0.76(0.65-0.90)$ & 3.9 & $1.8 \pm 0.2$ & NS \\
Monocrotophos +DEF & 328 & $0.54(0.42-0.69)$ & 3.8 & $1.3 \pm 0.2$ & NS \\
\hline
\end{tabular}

"Heterogeneity Chi-square kest; NS=not significant.

\section{Helicoverpa assulta bioassays}

Both the April 1993 and July 1993 strains collected from Datura were fully susceptible to the two test pyrethroids (table 2). Less than one-fold variation in LD 505 was recorded between the two strains when assayed with cypermethrin. and differences in probit parameters were only marginally significant (Position and Parallelism $\chi^{*}$ s, $P<0.05$ ). No significant heterogeneity was recorded $\left(\chi^{2}, P>0.05\right)$, and slopes at 1.8 and 2.4 were moderately high. For fenvalerate. inter-strain variation was slightly higher, with a 1.6-fold variation in $L D_{w s}$ and significant differences in position and parallelism of Idp lines ( $\chi^{2}$ s, $P<0.001$ and $P<0.05$ respectively). Slopes at 2.2 and 3.1 were high and the test populations were homogeneous with respect to fenvalerate susceptibility (Heterogeneity $X^{2}, P>0.05$ ). Pre-treatment with pbo did not synergize either cypermethrin or fenvalerate toxicity (Position $\chi^{2}, P>0.05$ ).

Ondy one strain was assayed with endosulfan, quinalphos and monocrotophos. The relatively steep latp slopes, low $L D_{\text {sos }}$ (in relation to the other two species), and lack of heterogeneity $\left(\chi^{2}, P>0.05\right)$ indicated that this strain was susceptible to endosulfan and both organophosphate insecticides. Pre-treatment with DEF resulted in a low level (2.5-\{old), but significant (Position $\chi^{2}, P<0.001$ ), synergism of quinalphos. Monocrotophos was not synergized by DEF (Position $\chi^{2}, P>0.05$ ).

\section{Heliothis peltigera bioassays}

Idp parameters were indieative of full susceptibility to the two test pyrethroid insecticides (table 3). Neither cypermethrin nor fenvalerate recorded major inter-strain differences in toxictity between the November 1992 and July 1993 collections (Position $\chi^{2}, P>0.05$ ). Slopes were high, ranging from 2.2-3.4. In general, pbo acted as a significant pyrthuroid inhibilor, decreasing the toxicity of cypemethrin and fenvalerate by 1- to 1.5-bold and 2. to 3-fold respect- ively (except for cypermethrin in 1992 where Position $y$. was not significant, in all other cases $\chi^{2}, P<0.001$ ).

Endosulfan $L D_{s 0}$ at $2.1-3.6 \mu \mathrm{g} /$ larva were surprisingly high. but steep Idp slopes (2.7-3.2) and lack of heterogeneity (Heterogeneity $y^{2}, P>0.05$ ), suggest that these data are indicative of the baseline susceptibility response for this species.

Tolerance to quinalphos and monocrotophos were 1.3. and 1.6-fold higher respectively in 1993 compared to 1992 (Position $\chi^{2}, P<0.01$ ). However, as there was no indication from the ldp lines of segregation of phenotypes and slopes were reasonably high (more so for quinalphos), there is no reason to assume that these data do not fall in the normal susceptible range. DEF did not significantly synergize quinalphos (Position $\chi^{2}, P>0.05$ ), but did cause a very low, 1.4-fold synergism of monocrotophos (Position $\chi^{2}$. $P<0.05$ )

\section{Light traps}

Trap catches are given as mean numbers of moths per trap per month (fig. 1). Helicoverpa amigera was by far the most abundant of the three species. On average, trap catches were one hundred times greater than those of $H$. assulta and Heliothis peltigera. Averaging the thirteen years trap data showed that there were two distinct peaks of Helicoverpa amigera moth activity on the IAC farm each season. The first, smaller peak in September (av. 840 moths/trap/month) was associated with moths emerging from infestations on wild hosts which grew prolifically on the farm with the onset of the monsoon rains in June, and from early sown sorghum crops. The second, much larger peak in November to December (av. 1500-2300 motha/month), was attributed to moth emergence from medium and late duration pigeon. pea cultivars which were major crops grown on the IAC farm during the years that the light traps were operated. Low catches (90-320 moths/month), between January and May were associated with moths emerging from chickpea, 


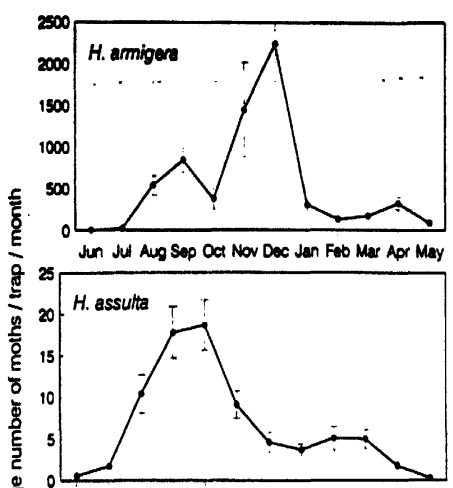

Jun Jul Aug Sep Oct Nov Dec Jan Feb Mar Apr May

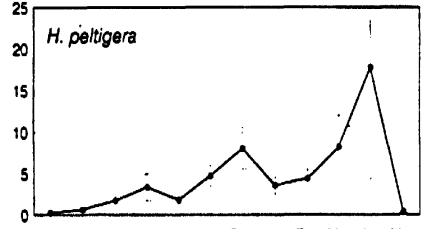

Jun Jul Aug Sep Oet Nov Dec Jan Feb Mar Apr May

Fig. 1. Average monthly catches of Helicoverpa armigera. $H$. assulta and Heliothis peltigern in light traps at the ICRISAT farm. Hydera.

bad. from $197 \$-1987$. Error bars represent standard errors.

groundnut and wild hosts. The lowest catches $(<7$ moths/trap). occurred in June because of the dearth of locally available larva! host plants on and around the IAC farm during the hot summer months of April and May.

Helicoverpa assulta catches were highest between August and November, peaking (av. 18-19 moths/trap/month) in September and October. It is likely that the abundance of $H$. assulta at this time was due to moths emerging from infestations on Datura between July and September. This host is present throughout the season, but peak growth and flowering occurs during the rainy season from July to September.

Heliothis peltigera catches were low throughout most of the year, only exceeding five moths/trap/month from December to April. The largest moth catches coineided with the vegetative and flowering periods of safflower crops from November to March and with the prescence of the wild host Acanthospermum hispidum (star burr). growing in irrigated groundnut fields on alfisols in February to March. $H$. pelligera catches were low during the rainy eason Oune to October), because larvae are highly parasitized by mermithid nematodes during this period. Bhatnagar et al. (1985) recorded up to $90 \%$ parasitiem of $H$. peltigera by mermithids on short stature hosts, such as $A$ hispidum growing on well drained alfisols, between June and
September in the late $1970 \mathrm{~s}$. We have recorded similar parasitism levels in the early 1990s Uadhav, unpublished data). By late October to early November. mermithid parasitism becomes insignificant because the nematodes are inactive during the dry post-rainy season (Bhatnagar ot al. 1985).

\section{Discussion}

The high $L D_{s 0}$ and $L D_{w}$ values coupled with relatively low slopes for Helicoverpa armigera assayed against endofulfan and selected pyrethroid and organophosphate and insecticides, indicate that this species is resistant to endosulfan and at least some members of the pyrethroid and organophosphate groups in the Hyderabad region, as reported earlier by MeCaffery at al. (1989) and Armes at al. (1992a). Baseline susceptible strain responses determined previously in our laboratory (Armes et al., 1992a and Armes. unpublished data), show that resistance levels to cypermethrin, endosulfan and quinalphos in the April 1993 strain were of the order of 140-, 17. and 11.fold respectively, and 28-, 5- and 5-fold respectively for the July 1993 strain. The higher resistance levels recorded in the April strain com. pared to the July strain were expected, as larvae collected at the end of the cropping season (March to April), are the progeny of five to six generations that have been exposed to insecticide selection during the previous nine to ten months (Armes et al., in press). As H. armigera populations are much reduced in density during the April to May summer period. as most crops have been harvested by this time, the net result is less insecticide being targeted against $H$. ammigern. This reduced selection allows some reversion toward susceptibility between April and July each year.

The low LD values and relatively high idp slopes recorded for $H$. assulta show that there was no sign of resistance having developed to any of the chemical groups rested on this species. Further, the lack of synergism, of pyrethroids with pbo and monocrotophos with DEF, indicates that metabolic insecticide detoxification mechanisms were not significant. The 2.5.fold synergism of quinalphos by DEF is sufficiently low to be indicative of the normal susceptible range. The lack of resistance in this species is not surprising because the only commercial host of $H$. assulta in India is tobacco. As it only feeds on the inflorescence and there is no leaf damage, it is therefore not considered an economic pest and consequently not subject to insecticide application. It is unlikely therefore that this species is subject to significant insecticide selection in India. This differs from some south-east Asian countries where $H$. assulta is a pest of Capsicum spp., and is frequently sprayed with all groups of commercially available insecticides; in South Korea for example, poor control of $H$. essulta has been attributed to the development of insecticide resistance (Lee \& $B 00$, 1985).

The Idp data for Heliothis peltigera were indicative of full susceptibility to pyrethroid, endosulfan and organophosphate insecticides in 1992 and 1993. The low toxicity of endosulfan was not expected (2-3 times less than against susceptible Helicoverpa amigera (Ames of al., 1992a)). Innate tolerance to this chemical, rather than resistance per $\boldsymbol{u}$ is suspected. Despite the high toxicity of both cypermethrin and fenvalerate and the steep slopes indicative of susceptibility, pbo acted as a significant (up to 3 -fold) pyrethroid inhibitor in both strains. Whether or not this was due to pbo facilitating penetration of the insecticide through the cuticle 
(Sun \& Johnston 1972), or to it inhibiting metabolic detoxification of the pyrethroid is not known. Heliothis peltigera has most probably remained susceptible to insecticides because the only commercial host where it may be subject to insecticide selection pressure is saftlower. Usually this crop is unsprayed. but when Halicoverpa armigera and/or Heliothis peltigera populations are sufficiently high to cause economic damage, 1-3 sprays may be applied.

The Idp results for both Helivoverpa assulta and Hetiothis peltigera provide important baseline toxicity data which can be used as standards against which future changes in susceptibility in these species in the Indian subcontinent, and to some degree elsewhere in Asia, can be compared.

Helicoverpa armigera has become resistant to insecticides because of its wide crop host range within agro-ecosystems and particularly high abundance on high value commercial crops where insecticides are extensively used (Reynolds \& Armes. 1994). On the other hand $H$. assulta and Heliothis peltigera are far less common species. and it is likely that their populations are moderated on wild hosts by natural enemies. Their very minor pest status on only one commercial crop each, means that they are not subject to intense insecticide selection pressure. This is not to say that the importance of these two species may not change in the future as cropping practices alter. For example, safflower production is increasing as the demand for polyunsaturated oils increases. In the major safflower producing state of Maharashtra, the area planted to safflower had increased from $49+, 000$ ha in $1981-82$ to 628,000 ha in $1989-90$ (Anon., 1993). Escalaking market prices for edible oils will induce farmers to grow larger areas and attempt to maximize yields by applying insecticides. If such a scenario does occur the pest status of $H$. peltigera could well change. Helicocierpa amigera is a case in point: less than twenty years ago it was not a significant pest on cotton in most seasons (e.8. Agarwal \& Cupta, 1983), but is now the major pest on this erop throughout the Indian subcontinent. Increasing dependence on insecticides for cotton pest control. possibly also coupled with changes in cotton cultivars since the early 1970s, brought about a marked change in the cotton pest complex. Pest species such as Spoduptera litura (Fabricius) and Earias spp. (Lepidoptera: Noctuidae) are now minor pests, having largely been displaced by $H$. armigera in South India and a combination of $H$. armigera and Bemisia tabaci (Gennadius) (Homoptera: Aleyrodidae) in the North (Reed \& Pawar, 1982; Anon., 1989).

Insecticide resistance management strategies for coltion pests are being developed in a number of countries in the Indian subcontinent and resistance monitoring has become an important component of these strategies, particularly in India (Ames at al, 1994, in press) and Pakistan (Denholm. 1993). Clearly it is important to ensure correct ppecies identification as management strategies for resistant and susceptible populations may differ appreciably (e.g. Dowling 1993). Furthes, if mixed species samples are bioassayed inadvertently, this will significantly affeck resistance frequency estimates in a discriminating dose monitoring programme or give misleading ldp assay resulks. At present the Haliothis species complex in the Indian subcontinent is not well understood. In Pakistan for example. Heticosenpa amigera and $H$. assulta are known to exist, but the two species are frequently confused, and the relative importance of the two species on field crops has not been documented (Mohyuddin 1989; M. Cahill, personal communication). Heliothis peltigera has not been reported from Pakistan, but in view of its distribution across Asia Minor and India. is likely to be present. In India, there are published reports of Halicooerpa assulta and Holiothis pothigera on cotton and pizeonpea (Cajanus cajan) (Bilapate, 1984). However, in our intensive surveys of Heliothis on field crops in central and southem India over twenty years, we have never found either species on these hosts. It is likely that species determination is often incorrectly made on the basis of larval coloration without checking the taxonomic characters of the larvae or adults (Hardwick 1965; Matthews. 1991). It is hoped that this paper may stimulate further studies on the distribution, host plant dynamics and resistance status of the Hetiothis complex in the subcontinent.

\section{Acknowledgements}

Financial support was provided by the Natural Resources Institute, UK through an Adaptive Research Initiative of the UK government's Overseas Development Administration. We thank K.V.S. Satyanaryana and M. Satyanaryana of ICRISAT's Crop Protection Division for technical assistance. Submitted as ICRISAT

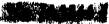

\section{References}

Abbott. W.S. (1929) A method for computing the effectiveness of an insecticide. Journal of Economic Entomology 18, 265-267.

Agarwal, R.A. \& Gupta, C.P. (1983) Insect pests of fibre crops. PP. 1+7-16+ in Srivastava, P.D. Jotwani. M.C. Agarwal, R.A. Wadhi. S.R. Bhanotar, R.K. \& Bhamagar, R.K. (Eds.) Agricultuml Entomology Vol.2. New Delhi. India, All Indla Science Writer's Society.

Anon. (1970) Standard method for the detection of insecticide resistance in Haliothis zea (Boddie) and H. virescms (F.). Bulletin of the Entomological Socirty of America 16. 1+7-133.

Anon. (1989) Management of whitefly, Bemisia tabaci C. on cotton. Technical Bulletin No. 11. Andhra Pradesh Agricultural University, Rajendeanagar, Hyderabad India.

Anon. (1993) Indian Agrieultural Statistics 1985-86 to 1989-90. Issue 37. Vol. I. Directorate of Economies and Statistics. New Delhi.

Armes, N.J., Jadhav, D.R., Bond, C.S. \& King, A.B.S. (1992a) Insecticide resistance in Helicoverpa armigera in South India. Pesticide Science 34, 355-364.

Armes, N.J., Bond, C.S. \& Cootet, R.J. (1992b) The laboratory culture and development of Helieverpa armigura. Natural Recoures Institute Bulletin 57, Chatham UK Natural Resources Intitute.

Armes, N.J., Banerjee, S.K., DeSouza, K.R., Jadhav, D.R. King A.B.S. Kranthi, K.R., Refupathy, A., Surulivelu, T. \& Venugopal Rao, N. (1994) Insectidde resistance in Holicooerpa amigers in India: recent developments. pp. 437-442 in Brighton Crop Protection Conformer - Pasts and Dienes 1994.

Armes, N.J., Jadhav, D.R. \& Lonorgan, P.A. (in press) Insectidide resistance in Halicoorpa armigera (Habner): status and prospects for its management in India. Proceudings of the Worls Cotton Research Conferenct - 1. 13-17 Fabruery 1994, Brisbane. Australia.

Avldov, Z. \& Harpas, 1. (1969) Plant Pests of Lrad. Jerusalem. Iscad University Press. 
Bhatnagar, VS. \& Davies. J.C. (1978) Factors affecting popuLations of gram pod borer, Heliothis armigma (Hübner) (Lepidoptern. Noctuidae) in the period 1974-77 at Patancheru, India. Bulletiu of Entomology 19, 32-64.

Bhatnagar, V.S. Pawar, C.S., Jadhav, D.R. \& Davies, J.C. (1985) Mermithid nematodes as parasites of Heliothis spp. and other crop pests in Andhra Pradesh, India. Proceedings of the Indian Academy of Sxiences (Animal Stiences) 94. 509-515.

Bilapate. C.C. (1984) Heliothis complex in India - a review. Asricultural Review 3. 13-26.

Cho, J.R. \& Boo, K.S. (1988) Behavior and circadian thythm of emergence. copulation and oviposition in the Oriental tobacco budworm Heliothis assulta Guenee. Korean joumal of Applied Entomology 27, 103-110.

Denholm, I. (1993) ICP/JBL Insecticide resistance monitoring project in Pakistan. Unpublished consultant's report to the Insecticide Resistance Action Committee. Rothamsted Experimental Station, UK.

Dowling. D. (1993) New resistance strategy to hinge on Heliothis identification test. The Australian Cotton Grouser 14, 14-15.

Finney, D.J. (1971) Probit analysis (2ndedn). Cambridge, Cambridge University Press.

Hardwick, D.F. (1965) The com earworm complex. Memoirs of the Entomological Society of Canada No. 40.

Ibrahim, A.A.El-Hamid \& Fayad, Y.H. (1989) Distribution and economic importance of Heliothis spp., their natural enemies. and host plants in Egypt. Pp. 174-170 in King. E.C. Jackson. R.D. (Eds.) Proceedings of the Workshop on Biological Control of Heliothis: Inereasing the Effectiveness of Natural Enemies. 11-15 Nov. 1985, New Delhi. India. New Delhi. FERRO, USDA.

King. A.B.S. (1994) Heliothis/Helicoverpn (Lepidoptera: Noctuidae). Pp. 39-106 in. Matthews. C.A. \& Tunstall, J.P. (Edg.) Insect pests of cotton. Wallingford. UK. CAB International.

Lee, K. \& Boo, K.S. (1985) Studies on biology and control program of the oriental tobacco budworm, Heliothis assulta. with insect growth regulators and sex pheromone. II. Effects of an insect growth regulator, diflubenzuron, on embryonic and postembryonic development. Agricultural Research Seoul National University 10. Suppl. 1. 27-34.

Manjunath, T.M., Patel, R.C. \& Yadav, D.N. (1976) Observations on Heliothis peltigera (Schiff.) (Lep.. Noctuidae) and its natural enemies in Anand (Gujurat State, India). Proceedings of the Indian Acadamy of Sciences 83, 55-65.
Manjunath, T.M., Bhatnagar, V.S. Pawar, CS. Sithanantham, S. (1989) Economic importance of Haliothis spp. in India and an assessment of their matural enemies and . host plants. pp. 197-228 in King. E.G. \& lackson, R.D. (Eds.) Procerdings of the Wiorkshop on Biological Control of Heliothis: Increasing the Effectiveness of Natural Enemies. 11-15 Nov. 1985. New Dilhi, India. New Delli, FERRO, USDA.

Matthews. M. (1991) Classification of the Heliothinae. Natural Resources Institute Bulletin 44. Chatham, UK, Natural Resources Institute.

McCaffery, A.R., King, A.B.S., Walker, A.J. \& El-Nayir, H. (1989) Resistance to synthetic pyrethroids in the bollworm. Heliothis amigera from Andhra Pradesh, India. Pesticide Science 27. 65-76.

Mohyuddin, A.I. (1989) Distribution and economic importance of Heliothis spp. in Pakistan and their natural enemies and host plants. Pp. 229-240 in King. E.C. \& lackson, R.D. (Eds.) Procendings of the Workshop on Biological Control of Heliothis: Increasing the Effectioeness of Natural Enemies. 11-13 Nov. 1985. New Delhi, India. New Delhi, FERRO, USDA.

Pawar, C.S., Bhatnagar, V.S. \& Jadhav, D.R. (1985) Heliothis species and their larval parasitoids on sole and intercrop safflower in India. Insect Science and its Application 6, 701-704.

Reed, W. \& Pawar, C.S. (1982) Heliothis: alobal problem. pp. 9-14 in. Proceedings of the Intermational Workshop on Heliothis management. 13-20 November 1981. International Crops Research Institute for the Semi-Asid Tropics (ICRISAT). Patancheru, Andhra Pradesh, India.

Reynolds, D. \& Armes. N. (1994) When insecticides fall: the case of the cotton bollworm in India. pp. 39-42 in World Agriculture 1994. London, Sterling Publications.

Ross, C.J.S. (1987) MLP Maximum likelihood program. The Numerical Algorithms Croup, Rothamsted Experimental Station, UK.

Sun, Y.P. \& Johnston, E.R. (1972) Quasi-Jynergism and penetration of insecticides. Journal of Economic Entomolugy 65, 349-353.

Yathom, S. (1971) Distribution and fight period of Heliothidinae species in Israel in 1959-1969. Israel Jounual of Agrizultural Research 21, 51-61.

(Accepted to lanuary 1996) C CAB NTERNATIONAL. 1996 